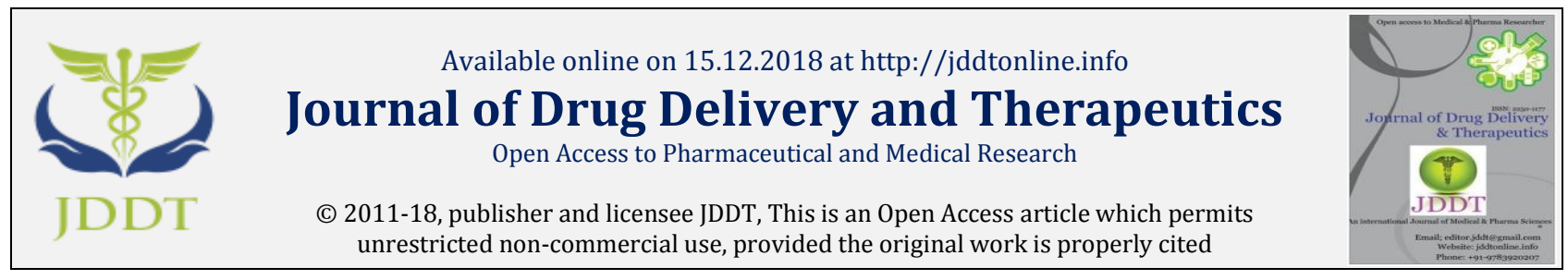

Open $\odot$ Access

Review Article

\title{
Management of Anidra through Ahara-Vihara, Natural Herbs and Shodhna Therapy: A Review
}

\author{
Dr. Seema G Chawardol1*, Dr. Sapan Jain ${ }^{2}$, Dr. Sanjeev Khuje ${ }^{3}$, Dr. Jinesh Kumar Jain ${ }^{4}$ \\ 1Professor, Panchkarma, Government Ayurved College, Nanded, India. \\ 2Professor, Kayachikitsa, Jupiter Ayurved Medical College, Nagpur, India. \\ ${ }^{3}$ HOD, Reader, Rognidan \& Vikruti Vigyan, Government Ayurved College, Rewa, India. \\ ${ }^{4}$ HOD, Reader, Panchkarma, Government Ayurved College, Rewa, MP, India.
}

\begin{abstract}
Ayurveda the science of healthy living deals with physical, mental and spiritual components of health. Ayurveda considered Ahara, Nidra and Brahmacarya as important parts of life for achieving goal of Swasthavritta. Nidra is a state of complete physical and mental relaxation of body which play vital role towards the good health status. There are some factors which may disturb physiology of Nidra leading to condition of sleeplessness/insomnia (Anidra). Anidra is abnormal physiological condition which greatly affects quality of life and this problem increasing day by day due to the enhanced level of stress, diversified environmental condition, disturb pattern of life style and bad dietary habits. It is very important for physician society to put focus attention to reduces prevalence of this issue. Ayurveda mentioned different therapeutic approaches for the management condition of insomnia including use of natural herbs, formulation, Shodhna Chikitsa and good conduction of Ahara-Vihara. Present article explored ayurveda view on Anidra along with its treatment modalities.
\end{abstract}

Keywords: Ayurveda, Nidra, Anidra, Insomnia.

Article Info: Received 13 Oct, 2018; Review Completed 26 Nov 2018; Accepted 27 Nov 2018; Available online 15 Dec 2018

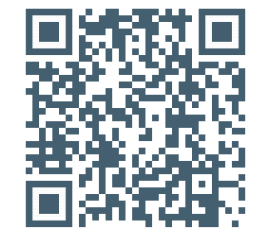

\section{Cite this article as:}

Chawardol SG, Jain S, Dr. Khuje S, Jain JK, Management of Anidra through Ahara-Vihara, Natural Herbs and Shodhna Therapy: A Review, Journal of Drug Delivery and Therapeutics. 2018; 8(6-s):344-346

DOI: http://dx.doi.org/10.22270/jddt.v8i6-s.2077

Dr. Seema G Chawardol, Professor, Panchkarma, Government Ayurved College, Nanded, India.

\section{INTRODUCTION}

Insomnia is one of the most common problems now a day's affecting large number of global population. It is associated with psychosomatic manifestations such as; fatigue, high blood pressure, loss of concentration, stress, anxiety, presence of other disease and conduction of disturbed daily regimen. Insomnia in Ayurveda termed as Anidra which may causes symptoms like; Dukha, Balahani, Karshyata and Agnyanata. As per ayurveda principle Vata Vaigunyata is mainly responsible for Anidra along with Mana and Indriya Vikaras. Ayurveda literature suggested that there are various diseases also associated with the Anidra such as; diabetes, psychological disturbances, eye problems, CNS disorders and digestive problems ${ }^{1-5}$.

The modern therapeutic approaches involve use of antipsychotic and sedatives drugs for the management of insomnia but these drugs may also have adverse effect like; abuse and addiction. Therefore it is very essential to have some safer approaches for the treatment of Anidra and
Ayurveda offers the same. Ayurveda mentioned different modalities for the management of insomnia including use of natural herbs, formulation, Shodhna Chikitsa and good conduction of Ahara-Vihara. Ayurveda also described yogic exercise (figure 1) for the management of insomnia ${ }^{2-4}$.

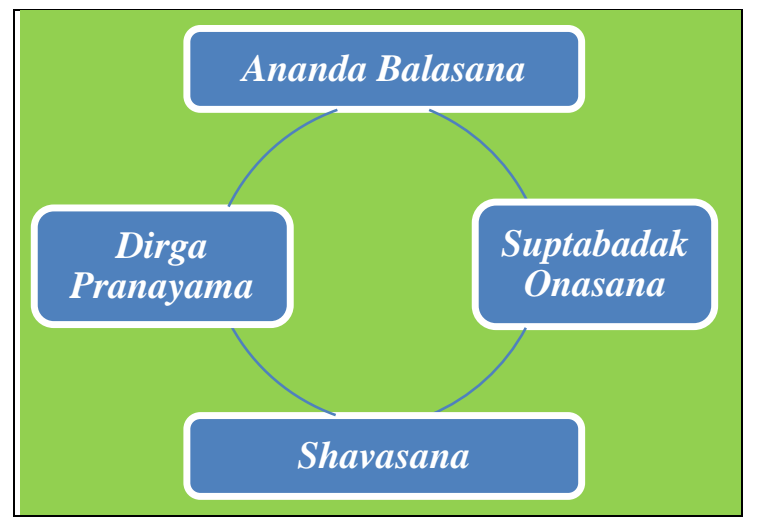

Figure 1: Yoga for Anidra. 


\section{Prognosis of Anidra:}

Anidra may involve vitiation of Vata Dosha associated with Upavasa, Atichinta, Asukha Shayaa, Atikrodha, Satvaaudarya, Karya, Tamojayee, Kala Vikara, Pita Vridhi, Abhighata and Atibhaya etc. Predisposition of Manasikakarana along with Tama Kshaya and Rajo Vruddi also induces prognosis of Anidra.

\section{Anidra may be associated with following internal factors:}

- Vitiation of Tama may disturb Tamobhava Nidra.

- Vitiation of Kapha may affect Slesmasamudbhava Nidra.

- $\quad$ Nidra associated with Manah-Sarira Srama Saambha disturbed during mental exertion.

- $\quad$ Presence of other diseases like; Sannipataja \& Jwara may lead Vyadhi-Anuvartini and disturbance in normal sleep.

- Factors such as; trauma and sock may vitiate Agantuka Nidra

\section{Physiological disturbances associated with} Anidra:

Anidra may offer following health disturbances:

- $\quad$ Anidra affect happiness, sterility and longevity

- Nourishment, strength, Satya Buddhi and Siddhi deteriorate due to Anidra

- $\quad$ Anidra may imbalances weight \& obesity

- $\quad$ Physical and mental fatigue may increase with Anidra

- Healing of external cuts and wound may delayed due to Anidra

- Anidra also affect process of natural growth and development

- Anxiety and stress associated with Anidra may deteriorate memory and mental power

- Anidra may disturb natural immunity and detoxification process

- Cardiac diseases, diabetes, blood pressure and psychological disturbance may be triggered with Anidra

- Sleep disturbances significantly affect bowel movement and gastric functioning thus imbalances process of digestion.

- Anidra may also leads physiological disturbances such as; Dukha, Klibata, Abala, Karshya, Ajnana Halimaka, head ache, rhinitis, giddiness and drowsiness 5-10.

\section{MANAGEMENT OF ANIDRA 6-11}

\section{Rules/Vihara to Eradicate Problem of Anidra:}

* Consumption of heavy, oily and spicy food should be avoided before sleeping

* One should follow to sleep during natural sleeping time (not too late/not too early)

* Be relaxed completely during sleeping time

* Comfortable positions for sleeping with extended body posture

* Oil massage may be helpful before sleeping time

* Dinner 2-3 hrs. before bed time

* Dhyana or meditation should be done before to go on bed

* Electronic gadgets such as; laptop and mobiles must be avoided before sleeping time

* Exercise and yoga practice help in Anidra

* Caffeine and tea should be avoided

* Day time sleep need to be avoid

* Bathing before sleep may help to induce sleep
* Chanting a Mantra and Japa etc. also recommended

\section{Ayurveda Herbs for Insomnia}

\section{Brahmi:}

- It acts as powerful brain tonic, supports and improves mental functioning.

- It offers calming and tranquillizing effect.

- Brahmi at bedtime may help to induce sleep.

- Brahmi help to control anxiety and stress.

Vacha:

- Vacha offers therapeutic benefits in various mental ailments such as; epilepsy, headache and insomnia etc.

- It relax mind and calm muscle fatigue.

\section{Aswagandha:}

- Aswagandha enhance vitality and longevity.

- It improves coordination between mind and senses.

- It is good to induces sleep.

- Aswagandha empowered mental status and relief anxiety.

\section{Jatamansi:}

- Increase levels of neurotransmitters serotonin thus enhance felling of well being.

- It acts as sedative, anti-depressant and relaxant.

- It is effective remedy for neurosis.

- Relax central nervous system and help to relief stress.

- Jatamansi control mental and physical fatigue.

\section{Valerian:}

- Valerian boosts nerve channels and cleans out toxins from nerve tissue.

- It acts as rejuvenating agent.

- Valerian in mild dose induces dulling effect which calms anxiety and stress.

- It is best when used with some herbal preparation.

\section{Ayurveda Formulation for Insomnia}

- Pipplimula churna

- Swamamakhshik Bhasma

- Vatakulantaka

- Nidrodaya rasa

- $\quad$ Triphala churna

- Asanadi Kashayam

- Varanadi Kashayam

\section{Panchkarma for Insomnia}

* Shirobasti, Shirodhara and Nasya offer excellent relief in anxiety, stress and insomnia.

* Abhyangam massage using anti-Vata oils like narayana or bala oils relaxes body, relief tensions and induces sleep. Brahmi oil massages on head region control insomnia.

* Vamana help to expel kapha dosha and thus prevent disturbances in sleep.

* Virechana expel toxins, dushti kapha \& pitta dosha therefore balances normal physiological functioning of body.

* Swedana help to clear channels, removes toxins, reduces fats and relax body therefore offer relief in sleep disturbances. 


\section{Dietary supplement for Insomnia:}

* Food containing multivitamin (vitamins A, C, E and Bcomplex vitamins).

* Food containing trace minerals (magnesium, calcium, zinc and selenium).

* Fish oil having omega-3 fatty acids.

* Food having 5-hydroxytryptophan, L-theanine, Melatonin and L-tryptophan.

* Hot, sour and spicy food should be avoided.

* Green leafy vegetables, wheat, rice, pulses and milk product may be recommended however junk food and heavy food must be avoid before sleep.

\section{CONCLUSION}

Nidra is one of the important aspects of life and play major role towards the normal physiological functioning of body. The incomplete sleep termed as Anidra (Insomnia) which may associate with various pathological conditions such as; Karshya, Dukha, Abala, Klibata, mental stress, head ache and feeling of heaviness etc. The problem of insomnia increasing currently day by day due to the stressful life; deteriorated environmental condition, imbalanced pattern of life style and misconduct of dietary regimen. Ayurveda literature established various therapeutic approaches for the management of Anidra such as; use of natural herbs, Ayurveda formulation, Shodhna Chikitsa and disciplined conduction of Ahara-Vihara.

\section{REFERENCES}

1. Barclay NL, Gehrman PR, Gregory AM, Eaves LJ, Silberg JL. The heritability of insomnia progression during childhood/ adolescence: results from a longitudinal study. Sleep. 2015; 38(1):109-18.

2. Chen HY, Shi Y, Ng CS, Chan SM, Yung KK, Zhang QL. Auricular acupuncture treatment for insomnia: a systematic review. J Altern Complement Med. 2007; 13(6):669-76.

3. Goto V, Frange C, Andersen ML, Junior JM, Tufik S, Hachul H. Chiropractic internvention in the treatment of postmenopausal climacteric symptoms and insomnia: A review. Maturitas. 2014; 78(1):3-7.

4. Harsora P, Kessmann J. Nonpharmacologic Management of Chronic Insomnia. American Fam Phys. 2009; 79(2).

5. Huang W, Kutner N, Bliwise DL. Autonomic activation in insomnia: the case for acupuncture. [Review].J Clin Sleep Med. 2011; 7(1):95-102.

6. Charak Samhita. Edited by Shastri K, Chaturvedi G. Sutrasthan. Chaukhambha Bharti Academy, Varanasi, 1998, 10.

7. Samhita S. Sharirasthan edited by Srikantha Murthy KR., Chaukhambha Orientalia, Varanasi, 2005, 630.

8. Charak Samhita. Sutrasthan edited by Shastri K, Chaturvedi G. Chaukhambha Bharti Academy, Varanasi, 2001, 227.

9. Chatterjee CC. Human Physiology, Medical allied Agency, Calcutta 1983; 2:267-68.

10. Shukla Vidyadhara. (2006). Charaka Samhita of Agnivesha, first edition, vol 1 Sutrasthana; Arthedhashmhamuliya adhayay: Chapter 30, verse (26), Varanasi Chaukhamha Surbharti Prakashan, 447.

11. Mishra Bramhashankara \& Vaisya Rupalalji. (2007). Bhavaprakash purvakhand 'Vidyodinee Tika', 11th edition, Vol 1, Purva Khanda; Dinacaryadi Prakarana: Chapter 5,verse (130), Delhi Choukhamba Sanskrit Sansthana Prakashan, p.121. 